University for Business and Technology in Kosovo

UBT Knowledge Center

UBT International Conference

2012 UBT International Conference

Nov 2nd, 9:00 AM - Nov 3rd, 5:00 PM

\title{
Managing the Rapid Urban Growth for Cities in Transition Countries
}

\author{
Binak Beqaj \\ University for Business and Technology, binak.beqaj@ubt-uni.net \\ Ylber Limani \\ University for Business and Technology, ylber.limani@ubt-uni.net \\ Driton R. Kryeziu \\ University for Business and Technology
}

Follow this and additional works at: https://knowledgecenter.ubt-uni.net/conference

Part of the Architecture Commons

\section{Recommended Citation}

Beqaj, Binak; Limani, Ylber; and Kryeziu, Driton R., "Managing the Rapid Urban Growth for Cities in Transition Countries" (2012). UBT International Conference. 1.

https://knowledgecenter.ubt-uni.net/conference/2012/all-events/1

This Event is brought to you for free and open access by the Publication and Journals at UBT Knowledge Center. It has been accepted for inclusion in UBT International Conference by an authorized administrator of UBT Knowledge Center. For more information, please contact knowledge.center@ubt-uni.net. 


\title{
MANAGING THE RAPID URBAN GROWTH FOR CITIES IN TRANSITION COUNTRIES
}

\author{
Dr.Sc. Binak Beqaj ${ }^{1}$, Dr.Sc.Ylber Limani ${ }^{1}$, Dipl.Ing. Driton R. Kryeziu \\ ${ }^{1}$ University for Business and Technology, Faculty of Architecture and Spatial Planning
}

\begin{abstract}
Through political transition, socio-economical trends of cities as urban areas contributed to huge movements of population from rural to urban areas or from small urban areas toward big urban areas, making them bigger, under the rapid growth. Those cities have faced:

- Overloads with number of citizens,

- Lack of adequate infrastructure and

- Creativity deficiency for drafting and implementing urban development vision.

Consequently, the question is what qualitative life do cities offer when considering abovementioned suppositions related to rapid urban growth?

In general, for cities under rapid development, experts and authorities have not sufficiently succeeded to develop proper methodologies to neutralize chaotically urban development trends for some inner or outer urban areas under the rapid growth, especially from countries in transition. In this context several reasons have been identified. Starting from not properly definition of land ownership and land destination, lack of urban development plans, not harmonized and not approved legislation framework, not established adequate mechanisms for monitoring and implementation of projects, lack of adequate expertise from specific fields, unsustainable transport modes, etc.

This paper identifies the possibilities that may lead to the success of urban management for strategic development of rapid growth for urban areas. The approaches for improvement and change should be based on multi-disciplinary actions from different organisational levels of society, proactively and in the same time acting on:
\end{abstract}

- Analytical aspect

- Planning aspect

- Organizational aspect

- Implementation aspect

Furthermore, this concept should be based on multi-sectorial expertise and partnerships between different actors dealing with the complexity of urban development. As main guideline for management of spatial city structure of cities under rapid urban growth, can be considered concept which is based on management of transition from existing to new developed urban areas and inter-relation between inner and outer urban areas. This concept may possibly include the development of new urban areas and renovation of existing ones, establishing transitional networks for implementing urban policies versus urban dynamics. In this way will be encouraged to redefine investments and to strengthen public-private partnership, as basic spatial development concept.

Key words: Urban rapid growth, management, transition cities, development, plans. 


\section{Introduction}

The rapid development trend of the cities in the World is going on; more than $50 \%$ of world's population lives in urban areas. In Europe, more than $70 \%$ of the population lives in urban areas at present. This figure is expected to increase to $84 \%$ by 2050 (Kabisch and Hasse, 2011). Most likely such development will have impacts and will produce effects with positive and negative implications. This rapid urban growth is becoming more problematic issue especially for Countries in transition because of impacts in urban quality of life for the citizens and for their development perspective.

Why this rapid and almost uncontrolled urban growth is happening? Except natural growth of population, the dominant role for the rapid growth of the cities is the movement of population from rural (not developed) areas to urban (developed) areas or from les developed urban areas to more developed urban areas (inter-urban movement of population). In developed countries these movements maybe described as a result of wealth increase and thereby mobility increase. However, in developing countries this phenomenon maybe mixed with the migration factor, i.e. the need for finding better life perspective and for security matters.

Migration from rural to urban areas has generally played an important role in the rapid growth of cities (UN, 2011).

The main question which can be raised is:

Are urban development policies well harmonized with urban dynamics in those urban areas which are under the pressure of rapid growth?

There are practices trying to involve all engaged groups in the development of approaches to mitigate the negative impacts of rapid urban growth. Some of such practices may be seen in the United Kingdom, e.g. the improved involvement of community and other partners in urban regeneration process (case studies:

The Partnership Council-Nottingham City and The Community Alliance-Sheffield City) ${ }^{1}$ [3]. In conclusion, the urban policies and urban dynamic are harmonized at moderate level, through existence of different networks organized which will contribute to the urban development processes. Those urban partnerships are aimed at promoting the interdisciplinary and proactive involvement of stakeholders in urban governance, either in local level or in central institutional level. However, these practices alone may not be sufficient to solve the issues raised from rapid urban growth. In this context this paper discusses the possibilities to improve the urban growth of cities in transition countries through provided case-based proactive approach.

\section{The methodology}

The discussions and findings in this paper are based on study of the interaction between different urban factors and different governance actors through urban regeneration processes. The study comprised a survey, statistical and documentary analysis and case studies in some selected urban areas. This paper briefly reviews some results from the case studies representing different urban environments assuming that different urban settings would influence an interaction between different urban stakeholders towards historical urban regeneration, specific program designs, local challenges and opportunities in line with integrative processes.

\section{Proactive approach for managing the rapid urban growth}

Good urban governance can be achieved if perception of the urban space will be interlinked as much as possible with functional relations, so, success of urban governance can be measured by achievements on:

1. Structural is sues (institutional structures, spatial structures, economical structures, infrastructure structures) and

2. Actions (leadership, policy, cooperation, innovation, integration).

Analyzing urban developments in the cities in transition, next question which can be raised is: How urban space can be integrated into urban governance?

\footnotetext{
${ }^{1}$ Urban-Community Initiative, Best Practice Handbook, EKOS limited, January 2000, pages 5 11
} 
The concept of doing some analyses about qualitative urban governance should be based on evaluation of two main indicators:

1. The level of cooperation and

2. The level of conflicts

All participants of the process are responsible to find solutions and to deal with transitory urban challenges:

- Demographic transformation

- Environmental decay and climatic changes

- Unequal social participation

- $\quad$ Ever rising mobility trends

Evaluating existing situation in context of sustainability

Table 1: The city of Vienna, evaluation

\begin{tabular}{l|lll}
\hline Vienna & & & \\
\hline Inhabitants & Growth & Transport & Identity \\
\hline $\begin{array}{l}\text { Vienna has 1.7 million } \\
\text { inhabitants }{ }^{2}[\mathbf{6}] .\end{array}$ & $\begin{array}{l}\text { During last 10 years } \\
\text { has increased for 10\% }\end{array}$ & $\begin{array}{l}\text { Only 29\% of transport } \\
\text { is based on private cars }\end{array}$ & $\begin{array}{l}\text { Vienna identity is } \\
\text { trying to be } \\
\text { transformed on "Smart } \\
\text { City" }\end{array}$ \\
\hline
\end{tabular}

Table 2: The city of Prishtina, evaluation

\begin{tabular}{l|lll}
\hline Prishtina & & & \\
\hline Inhabitants & Growth & Transport & Identity \\
\hline $\begin{array}{l}\text { Prishtina has } \mathbf{0 . 1 9 8} \\
\text { million } \\
\text { inhabitants }\end{array}$ & $\begin{array}{l}\text { During last 10 years } \\
\text { has increased for 100\% }\end{array}$ & $\begin{array}{l}\text { More than 80\% of } \\
\text { transport is based on } \\
\text { private cars }\end{array}$ & $\begin{array}{l}\text { Prishtina identity is } \\
\text { trying to be founded }\end{array}$ \\
\hline
\end{tabular}

\subsection{The analysis of a study case and the evaluation method - Map of Interactions}

The city of Vienna has been compared with the city of Prishtina regarding some urban development indicators . As displayed in the Tables 1 and 2; there is evidence of remarkable tangible differences between two cities. Those indicators show the possibility of major impacts of urban developments in Prishtina city in related fields like: growth, transport and identity, which are expected to happen in higher magnitude in the absence of immediate undertakings.

Evaluation of existing urban conditions in Prishtina, in context of good urban governance is based on methodology used: 4x4x4- Map of Interactions

This evaluation methodology has been based on four categorized evaluation steps, using four defined urban functions in relation with four levels of urban space.

The first assumption is to categorize four evaluation steps as follows:

1. Good (+)

2. Neutral (+-)

3. Low (-)

4. $\operatorname{Bad}(0)$

The second assumption is to categorize four urban functions as follows:

1. Regulative functions

2. Habitat functions

3. Productions functions

${ }^{2}$ Book of abstracts EURA 2012

${ }^{3}$ Kosovo Agency for statistics, REKOS 2011 


\section{Information's functions}

The third assumption is to categorize four urban levels of urban space as follows:

1. Urban

2. Inner urban

3. Outer urban

4. Rural

The outcome delivers with a map of interactions as presented in Figure 1.

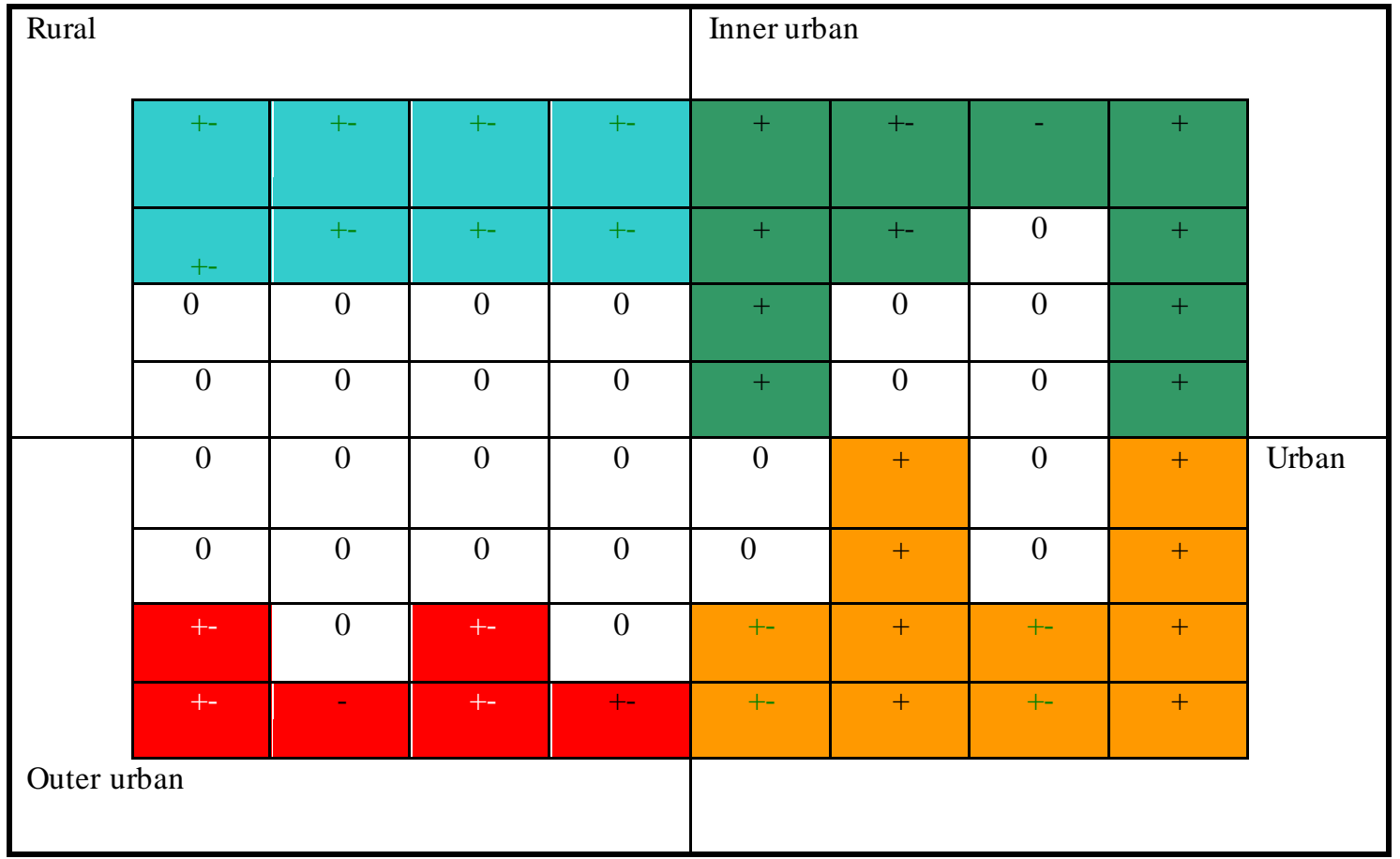

Figure 1: The evaluation method 4x4x4-Map of Interactions

Subsequently, the assumption is to bring these evaluation results in relation with following integrative process of urban governance.

Considering results presented in Figure 1, and comparing them with each other for different urban space levels, the outcomes of transforming urban space into urban governance should be based on:

Planning agenda dedicated to:

- Economy and innovation

- Mobility

- Society

- Ecology

\subsection{Evaluating existing situation in context of initial- circle of changes}

Good governance should be based on achievements. It depends to which level of governance system cities are related:

1. Centralized -hierarchy or

2. Decentralized -competence

Evaluation presented below will help for better understanding, what do city have and if this is in line with visible positive results needed towards four long term city images identified until now: 
- Entrepreneurial city 2050;economic vitality and innovation

- Connected city 2050; smart logistics and sustainable mobility

- Pioneer city 2050;social participation and social capital

- Livable city 2050; ecologic sustainability

The figures 3 and 4 represent the urban development conditions of the city of Bremen and the City of Prishtina. The example is supposed to support the assumptions made in the case study of the comparison between th ose two cities. The results from these comparisons and the methodology used are aimed at providing urban planners and governmental responsible departments of transition countries with an insight of the existing conditions and the tool for identification of critical development issues.

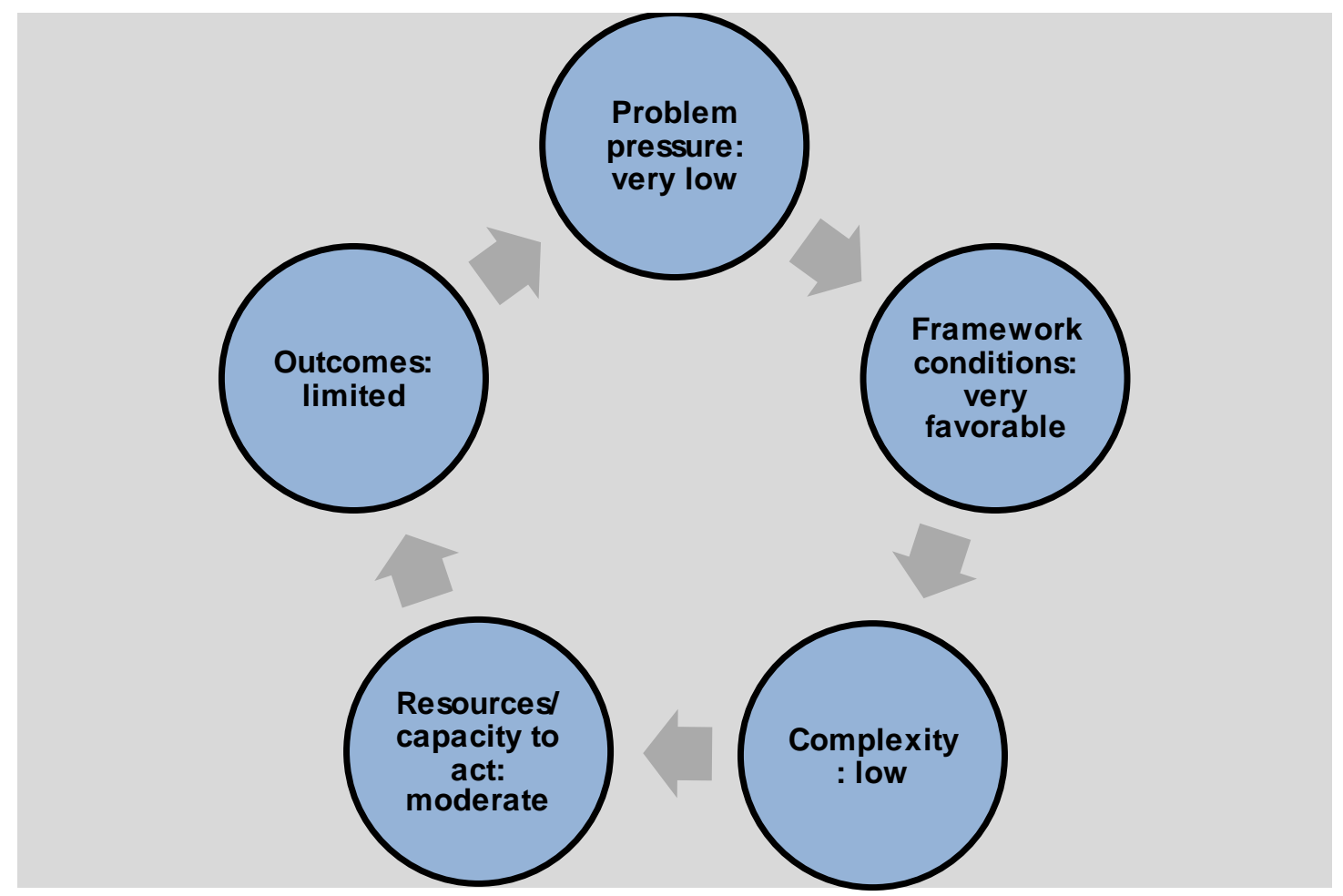

Figure 3: Bremen City, initial change circle 


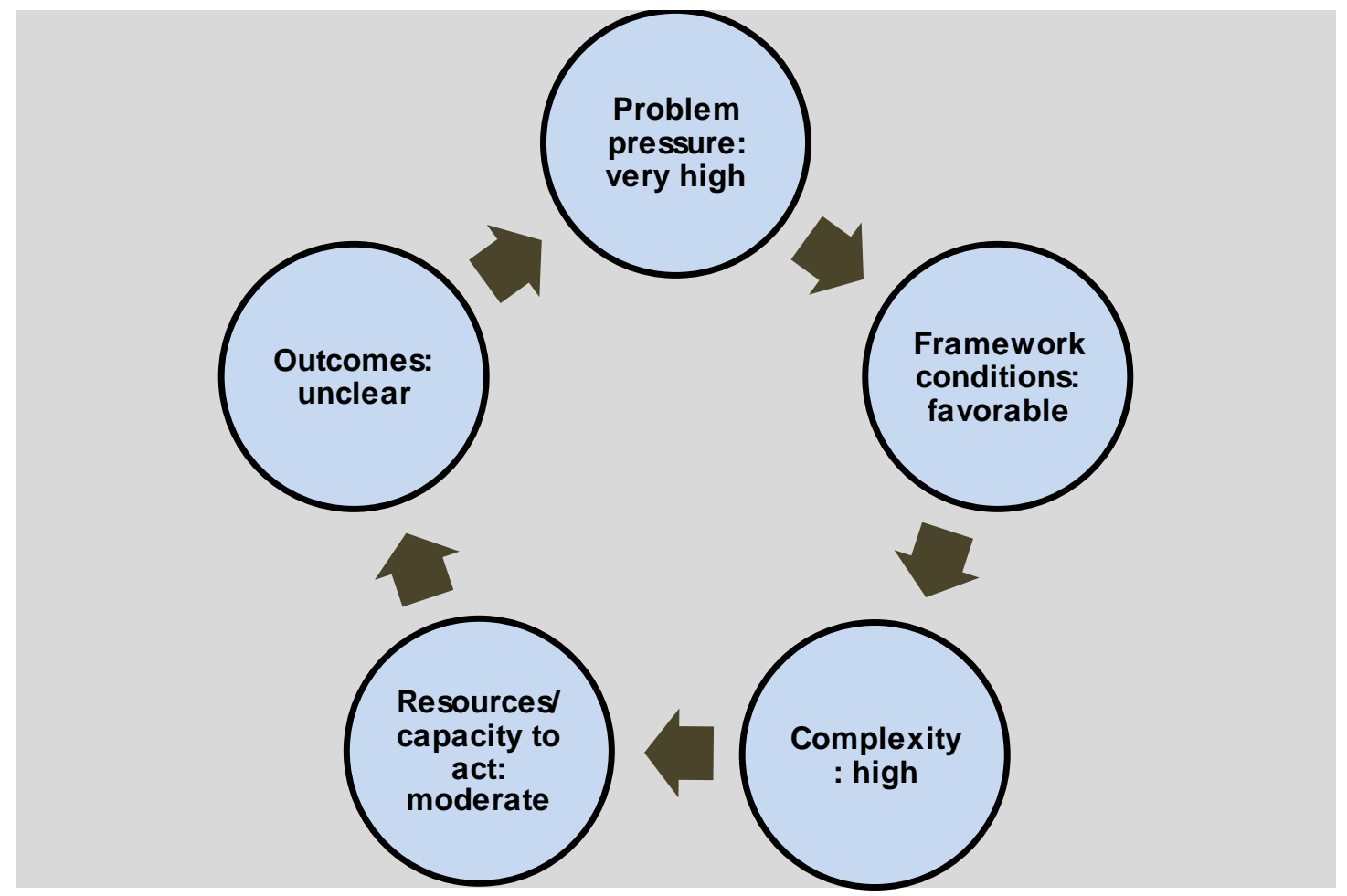

Figure 4: Prishtina City, initial change circle

Summarizing, to have good governance means creating integrative policy related to: sectors, disciplines and institutions. As result of that changes should be measurable and challenges should be transformed into good practice through following concept of sustainable development based urban indicators:

1. Social - stakeholders' inclusion

2. Economic -strategic thinking

3. Politic - accountability and responsibility

4. Environmental -fairness and justice

\section{Results}

From the Tables 1 and 2: the most identified is sues that require immediate response are: the mitigation of urban sprawl and building an sustainable and comprehensive transport system in transitional urban areas.

\begin{tabular}{|c|c|c|c|c|c|c|}
\hline & $\begin{array}{l}\text { Problem } \\
\text { pressure }\end{array}$ & $\begin{array}{l}\text { Framework } \\
\text { conditions }\end{array}$ & Complexity & $\begin{array}{l}\text { Resources } \\
\text { capacity to } \\
\text { act }\end{array}$ & Outcome & \begin{tabular}{l}
\multicolumn{2}{r}{ From } \\
Figure 3 \\
and $4:$
\end{tabular} \\
\hline Prishtina & Very high & Favorable & High & Moderate & Limited & Results \\
\hline $\begin{array}{l}\text { Bremen } \\
\text { Difference }\end{array}$ & Very low & Very favorable & Low & Moderate & Unclear & $\begin{array}{l}\text { of the } \\
\text { comparis }\end{array}$ \\
\hline magnitude & High & Medium & High & Low & High & \\
\hline
\end{tabular}

city of Prishtina and city of Bremen in the context of initial circle of change, the most identified issues that require immediate response are: the problem pressure for development and their complexity related to outcomes from the process. 


\section{Conclusions}

Concluding that Urban Planning should be based on research and good governance able to support innovation and its implementation always assuring livability and accessibility of urban area.

Establishing the vision and answering the question: How city under rapid growth can be transferred into proactive city with capacity to develop and recover from growth pressure? Is another task that can be reached through clear planning concept based on: potentials and resources; collaborative planning; active participation of stakeholders and networks.

Using common features: institutional framework and legal regulations and defining position of community in the process as: structure- more for big cities or actor-more for small cities; for dealing with main transitory urban challenge:

- Integration of contributions from government, community and business as unified governance system

Towards urban Europe!

\section{References}

[1]. Lawless, Paul (2011) Big Society and Community: lessons from the 1988-2011

[2]. Mandell, M.P. \& Keast, R. (2008) Voluntary and Community Sector Partnerships

[3]. Urban-Community Initiative, Best Practice Handbook, EKOS limited, January 2000, pages $5-11$.

[4]. KABISCH, N. and HAASE, D. (2011) "Diversifying European Agglomerations: Evidence of Urban Population Trends for the 21st Century", Population, Space and Place, 17: 236-253.

[5]. UN (2011). Population Distribution, Urbanization, Internal Migration and Development: An International Perspective. United Nations Publication. http://www.un.org/esa/population/publications/PopDistribUrbanization/PopulationDistributionUrbanization.pdf

[6]. Book of abstracts EURA 2012, Vienna

[7]. Kosovo Agency for statistics, REKOS 2011

[8]. B.Beqaj (2007) Urban Management 